\title{
Detrimental impact of silica nanoparticles on the nanomechanical properties of Escherichia coli, studied by AFM
}

\author{
Marion Mathelié-Guinlet ${ }^{\mathrm{a}, \mathrm{b}}$, Christine Grauby-Heywang ${ }^{\mathrm{a}}$, Axel Martin ${ }^{\mathrm{a}}$, Hugo Février ${ }^{\mathrm{a}}$, Fabien Morotéa \\ Alexandre Vilquin ${ }^{\mathrm{a}}$, Laure Béven ${ }^{\mathrm{c}}$, Marie-Hélène Delville ${ }^{\mathrm{b}, *}$, Touria Cohen-Bouhacina ${ }^{\mathrm{a}, *}$ \\ ${ }^{a}$ Univ. Bordeaux, CNRS, LOMA, UMR5798, 351 cours de la Libération, 33400 Talence, France \\ ${ }^{\mathrm{b}}$ Univ. Bordeaux, CNRS, ICMCB, UMR5026, 87 avenue du Dr Albert Schweitzer, 33608 Pessac, France \\ ${ }^{\mathrm{C}}$ Univ. Bordeaux, INRA, UMR 1332 Biologie du Fruit et Pathologie, 33882 Villenave-d'Ornon, France
}

G R A P H I C A L A B S T R A C T

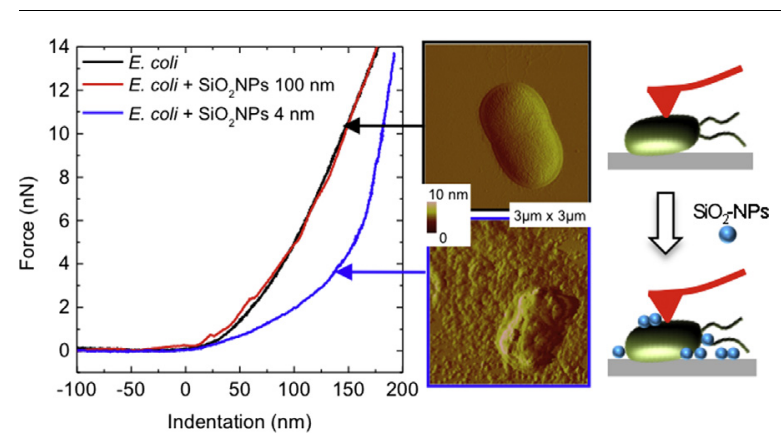

\section{A R T I C L E I N F O}

\section{Keywords:}

Bacterial surface

Nanoparticles

Elasticity

Toxicity

AFM

\begin{abstract}
A B S T R A C T
Despite great innovative and technological promises, nanoparticles (NPs) can ultimately exert an antibac terial activity by affecting the cell envelope integrity. This envelope, by conferring the cell its rigidity and protection, is intimately related to the mechanical behavior of the bacterial surface. Depending on their size, surface chemistry, shape, NPs can induce damages to the cell morphology and structure among others, and are therefore expected to alter the overall mechanical properties of bacteria. Although Atomic Force Microscopy (AFM) stands as a powerful tool to study biological systems, with high resolu tion and in near physiological environment, it has rarely been applied to investigate at the same time both morphological and mechanical degradations of bacteria upon NPs treatment. Consequently, this study aims at quantifying the impact of the silica $\mathrm{NPs}\left(\mathrm{SiO}_{2} \mathrm{NPs}\right)$ on the mechanical properties of E. coli cells after their exposure, and relating it to their toxic activity under a critical diameter. Cell elas ticity was calculated by fitting the force curves with the Hertz model, and was correlated with the mor phological study. $\mathrm{SiO}_{2} \mathrm{NPs}$ of $100 \mathrm{~nm}$ diameter did not trigger any significant change in the Young modulus of $E$. coli, in agreement with the bacterial intact morphology and membrane structure. On the opposite, the $4 \mathrm{~nm}$ diameter $\mathrm{SiO}_{2} \mathrm{NPs}$ did induce a significant decrease in E. coli Young modulus, mainly associated with the disorganization of lipopolysaccharides in the outer membrane and the permeation of the underlying peptidoglycan layer. The subsequent toxic behavior of these NPs is finally confirmed by the presence of membrane residues, due to cell lysis, exhibiting typical adhesion features.
\end{abstract}

\footnotetext{
* Corresponding authors.

E-mail addresses: marie-helene.delville@icmcb.cnrs.fr (M.-H. Delville), touria.cohen-bouhacina@u-bordeaux.fr (T. Cohen-Bouhacina).
} 


\section{Introduction}

The fast development of nanotechnologies has led to both a growing production and a release of nanoparticles (NPs) into the environment. Due to their unique properties, compared to their bulk counterpart, NPs raised a great interest especially for biomed ical applications such as theranostics [1 3 ]. However, they also raised concerns about their potential adverse effects on the health of living systems [4 10]. Notably, when released in air, water and soil, NPs can interact with bacteria necessary for the ecosystem safety, for instance our intestinal or cutaneous microbiota, and damage their integrity $[11,12]$. Cellular effects of NPs have shown strong dependence on multiple parameters such as their size, charge, shape and chemical nature [13 17], but also differ depend ing on cell species and environment [18 20]. Consequently, it is as essential as challenging to explore and to understand NPs/cell interactions to provide a safe and innovative development of nan otechnologies in medical or environmental applications, including alternative to antibiotics to specifically and efficiently target bacte ria [21].

Much evidence has indicated that the antibacterial activity of NPs takes place through the disruption of bacterial membranes [22,23], the production of Reactive Oxygen Species (ROS) [24,25] and/or the interference with the bacteria metabolism [26,27]. Up to now, the authors have focused on morphological, viability and enzymatic activity characteristics of cells, to probe the cytotoxic effects of NPs, through transmission electron microscopy (TEM) [28], Raman spectroscopy [29], flow cytometry [30] and/or Colony Forming Units (CFU) counting [31]. However, whatever the action mechanism, the very first step relies on the contact between the cell outest membrane and the NPs. The subsequent modifications of the mechanical properties of bacterial surface which may occur depend on the interaction dictated by the surface properties of each partner. These properties reflect the behavior of both the stiff and flexible materials which constitute the cell and are crucial for cell functions and viability [32,33]. Indeed, the overall mechanical properties of bacteria depend on intrinsic characteristics of the envelope such as its integrity, which might be altered by lytic fac tors of diverse nature [34]. In addition, the biochemical composi tion, the conformational properties and density of biomolecules in the cell envelope play an important role in the bacterial elastic ity [35]. The peptidoglycan layer likely dominates the elastic nat ure of the cell. Nevertheless, membrane lipids and proteins also contribute to this elasticity, inducing different viscoelastic responses between Gram negative and Gram positive bacteria [36]. In other words, changes in the mechanical features provide information on the changes occurring in the cell, either in its com position, its physiological activity or the conformation of its con stituent molecules. Such transformations also appear under specific environmental conditions (upon osmotic or $\mathrm{pH}$ changes) [37 39] or during cellular processes (cell growth, division, motion, adhesion or infection) [40,41]. Indeed, the bacterial survival depends on the capacity of the micro organisms to modulate these properties in response to changes in their close environment or during specific stages of their life cycle. Several recent studies have then pointed out the changes in mechanical properties of bacteria, at the local scale, upon treatment with antimicrobial peptides, and have provided useful insights to understand the effect of these compounds $[42,43]$. Their interaction with cells results in damages to the bacterial envelope: the loss of membrane lipids, the accumu lation of the bactericidal compound within the cell wall and the biochemical changes induce, in the end, a modification of the mechanical parameters (flexibility, adhesion, elasticity) [44].

In this context, investigating the mechanical properties of bac teria upon interaction with bacterial viability affecting NPs could help identifying the mechanism by which the particles interact with the bacterial envelope and exert their toxicity $[45,46]$. In the past decades, atomic force microscopy (AFM) has emerged as a powerful and suited tool to investigate such interactions and to solve many biological issues [45,47 49]. Indeed, not only AFM enables to image, in real time, biological systems with high resolu tion (10 $100 \mathrm{~nm}$ scale range) both in air and in physiological envi ronment, but also, with a force spectroscopy mode, it can probe simultaneously their mechanical properties at a molecular level [50 52].

In this study, our purpose was to investigate and probe the mechanical properties of $E$. coli, at the submicrometric scale, before and after exposure to silica NPs ( $\left.\mathrm{SiO}_{2} \mathrm{NPs}\right)$ with different sizes. On one hand, $E$. coli cells were chosen because they are widely used systems, either harmless or responsible for serious human dis eases. Their cell envelope consists of two lipidic membranes sepa rated by a thin peptidoglycan layer called the cell wall [53]. The outer membrane (OM), which constitutes the interface with the external environment, contains LipoPolySaccharides (LPS) forming a brush like structure at the cell surface. The inner membrane sep arates a gel like periplasm containing the peptidoglycan from the cytoplasm. In addition, they are ubiquitous in the environment and thus, highly exposed to interactions with NPs [54]. On the other hand, $\mathrm{SiO}_{2}$ NPs are considered as promising candidates for biomedical imaging, drug delivery, and biosensing applications [55]. Furthermore, despite their easy control in terms of size and surface chemistry, the antibacterial activity of $\mathrm{SiO}_{2} \mathrm{NPs}$ is not well documented and their mechanism of action is still unknown [56 58]. For such NPs, a toxicity towards E. coli was shown to depend on their charge and size [17]. Below a critical diameter $\Phi_{c}(50$ $\mathrm{nm}<\Phi_{\mathrm{c}}<80 \mathrm{~nm}$ ), morphological and membrane structural dam ages eventually led to cell lysis. To better understand the antibac terial effect of $\mathrm{SiO}_{2} \mathrm{NPs}$, AFM was here used mainly in force spectroscopy mode and in liquid to measure the Young modulus of $E$. coli cells, after their treatment with NPs with diameter of either $4 \mathrm{~nm}$ or $100 \mathrm{~nm}$ (called later $\mathrm{SiO}_{2} \mathrm{NPs} 4 \mathrm{~nm}$ and $\mathrm{SiO}_{2} \mathrm{NPs}$ $100 \mathrm{~nm}$, respectively). This work aims at quantifying the NPs/bac teria interaction based on the change in the mechanical properties of $E$. coli upon exposure to NPs. AFM force spectroscopy provides such a quantification, as well as a correlation with the morpholog ical and membrane characteristics of E. coli, obtained with AFM imaging either in air or in liquid, in tapping and contact modes respectively.

\section{Materials and methods}

\subsection{Materials}

Commercial $\mathrm{SiO}_{2}$ NPs $100 \mathrm{~nm}$ and $\mathrm{SiO}_{2}$ NPs $4 \mathrm{~nm}$ were pur chased from Biovalley (Marne la Vallée, France) and Alfa Aesar (Schiltigheim, France) respectively. Transmission Electronic Micro scopy (TEM) and Diffusion Light Scattering (DLS) measurements were performed to characterize these NPs. Though $\mathrm{SiO}_{2} \mathrm{NPs}$ $4 \mathrm{~nm}$ were highly aggregated on TEM cliches, an average hydrody namic diameter of $3 \mathrm{~nm}$ was determined by DLS. For the $\mathrm{SiO}_{2} \mathrm{NPs}$ $100 \mathrm{~nm}$, both technics were in agreement: statistics performed on TEM cliches gave an average diameter of $113 \pm 11 \mathrm{~nm}$ while the hydrodynamic one was found around $124 \mathrm{~nm}$.

Gram negative E. coli bacteria (MRE 162 strain) were a kind gift from the Centre d'Etudes du Bouchet, DGA (Direction Générale de l'Armement, France). Mica, purchased from Electron Microscopy Sciences (Hatfield, United States), was used as substrate for all AFM measurements. Luria Broth (LB) medium was used as nutritive medium and purchased from Fisher Scientific (Waltham, Massachusetts, United States). Millipore ultrapure water ( $\mathrm{pH} 5.5$, 
resistivity $>18.2 \mathrm{M} \Omega \mathrm{cm}$ ) was used for NPs cleaning and bacteria suspensions preparation. Polyelectrolytes, used in this work to immobilize bacteria on mica, are cationic Poly (Allylamine Hydrochloride) (PAH, MW $=56000$, pure at more than 95\%), and anionic Poly (sodium 4 Styrene Sulfonate) (PSS, MW $=70000$, conform infrared spectrum); they were purchased from Sigma Aldrich.

\subsection{Bacterial culture and interaction with NPS}

E. coli cells were grown on LB agar plates and incubated for $16 \mathrm{~h}$ at $37^{\circ} \mathrm{C}$. After scraping, bacteria were suspended in ultrapure water and their concentration was adjusted to $8.10^{8}$ cells $/ \mathrm{mL}$, cor responding to an optical density (at $600 \mathrm{~nm}$ ) of 1.0. Consequently, the studied bacteria are in the stationary phase of their growth. Though many experiments required buffer solution (like Phos phate Buffer Solution, PBS), we chose ultrapure water for conve nient reasons (to prevent the formation of PBS crystals for AFM characterizations in air, after the drying step) and because no bac terial mortality was observed in such simple solvent after $2 \mathrm{~h}$.

Then, $\mathrm{SiO}_{2}$ NPs (also dispersed in ultrapure water) were intro duced in the bacteria suspension at a final concentration of $1 \mathrm{~g} / \mathrm{L}$. The co suspension was mixed and gently manually shaken for homogeneity (4 times every $20 \mathrm{~min}$ ), then left to interact at room temperature for $2 \mathrm{~h}$. Five $\mu \mathrm{L}$ of the co suspension were deposited on either bare mica, for AFM observations in air, or on a PolyElec trolyte Multilayer (PEM, see below), for AFM observations in liquid.

\subsection{Substrate and sample preparations for AFM observation}

With an average roughness of $0.3 \mathrm{~nm} / \mu \mathrm{m}^{2}$, mica is perfectly sui ted for AFM imaging to discriminate any topographic contrast. Bare mica was, then, used in this work for all experiments carried out in air, mainly AFM morphological characterizations. If one wants to image bacteria in a more realistic environment such as a liquid, the sample needs to be fixed on the substrate first, to prevent any motion with the fluid flow. To do so, we successfully applied a sequential deposition of oppositely charged solutions of polyelec trolytes (PAH and PSS) [59]. Polyelectrolytes were dissolved in ultrapure water at a concentration of $0.5 \mathrm{~g} / \mathrm{L}$ and alternatively deposited through a spin coating process $\left(45 \mathrm{~s}, 100 \mathrm{rpm}, 200 \mathrm{~s}^{2}\right)$, starting with $\mathrm{PAH}$ on bare mica. Consequently, a (PAH PSS) ${ }_{3} \mathrm{PAH}$ PEM was formed to immobilize the negatively charged $E$. coli bac teria. This PEM exhibits an average thickness of $4 \mathrm{~nm}$, determined with scratching AFM experiments. Whatever the substrate (bare or functionalized mica), five $\mu \mathrm{L}$ of bacteria suspension, untreated or treated with NPs, were deposited on its surface before imaging.

\subsection{AFM observations}

AFM experiments were carried out using a Bioscope II operating with the NanoScope $V$ controller. For morphological characteriza tions, we used the tapping mode in air and in the repulsive domi nant mode, in order to prevent any damage to the samples. Images were obtained with commercial cantilevers with a spring constant around $40 \mathrm{~N} / \mathrm{m}$, at a scan rate of $0.51 .0 \mathrm{~Hz}$ and with a resolution of $512 \times 512$ pixels. For imaging in liquid (ultrapure water), we used the contact mode, with an applied force around a few $\mathrm{nN}$ to pre vent any damage or indentation of the sample. Data were obtained with commercial cantilevers with a spring constant of $0.12 \mathrm{~N} / \mathrm{m}$, at a scan rate of $1.0 \mathrm{~Hz}$. Different areas were systematically imaged and results shown thereafter are representative of the cells in a given set of colonies and of all the tested samples.

When imaging in air, the sample was first left to dry in a desic cator and imaged on the day following the preparation. On the other hand, when imaged in liquid, the sample was prepared and directly imaged.

\subsection{AFM force distance curves (FCs) acquisition}

In the force spectroscopy mode, the AFM tip is considered as a sensitive sensor, being pressed on the sample surface. Indeed, it is possible thanks to the cantilever to control and measure the applied force and to couple AFM imaging with the mechanical response at the local scale of the studied system [60]. During a FC acquisition, the tip is approached and then retracted from the surface: the former part of the FC can be used to measure the indentation of the sample and its stiffness, while the latter one gives information on the tip sample interactions, like adhesion. For FC measurements, triangular silicon nitride tips, with a spring constant of $0.120 .20 \mathrm{~N} / \mathrm{m}$ determined by the thermal noise method, were used. To obtain deflection sensitivity, calibrations were first carried out in air and then in ultrapure water. FCs were recorded in the central region of different cells, from highly aggre gated to isolated ones, to avoid any artifact related to edge curva ture. To statistically provide robust data, at least three independent experimental sets (bacterial samples from different cultures) were investigated, either treated with NPs or not, and in each set at least ten different bacteria were studied in different areas of the sample.

After FC acquisition, quantitative measurements of bacterial elasticity can be obtained through three distinct theories: (i) the Hertz model can be applied when adhesion is negligible compared to the load, (ii) the Johnson Kendall Roberts (JKR) model can be applied for large tips and soft samples with large adhesion and (iii) the Derjaguin Muller Toporov (DMT) model can be applied for small tips on stiff material with low adhesion [50]. Despite its limitations, especially concerning the uncertainty in the contact point determination and the assumed homogeneity and linear elasticity of the sample [61], the Hertz model has been one of the simplest and most widely used model to quantify the mechan ical properties of biological samples [48]. Consequently, we chose this model to fit our FCs. It gives access to the Young modulus, E, of the sample when this last one is indented by a tip with a known geometry (here conical) [62]:

$F \quad \frac{2 E \tan \theta}{\pi\left(1 \quad v^{2}\right)} \delta^{2}$

where $\mathrm{F}$ if the applied force, $\theta$ is the half cone angle of the tip (set to $25^{\circ}$ ), $\mathrm{U}$ is the Poisson ratio (assumed to be 0.5 for soft materials) and $\delta$ is the deformation of the cell due to the tip. The Young modulus is also linked to the stiffness of the sample, $\mathrm{k}_{\mathrm{S}}$, by the relation:

$k_{S} \quad E \frac{4}{\pi} \delta \tan (\theta)$

In practice, we obtained curves of the deflection, $\mathrm{d}$, according to the tip to sample distance, $z$. In parallel, we developed a Matlab routine to transduce these curves into those expressing the inden tation force, $\mathrm{F}$, as a function of the deformation, $\delta$. These two parameters were calculated according to the following relation ships [62]:

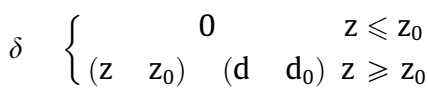

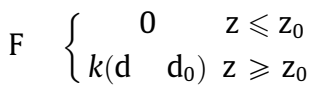

where $\left(z_{0}, d_{0}\right)$ are the coordinates of the contact point and $k$ is the cantilever stiffness.

Once the curve $F=f(\delta)$ was obtained, the Young's modulus of the sample was calculated by adjusting this curve with the above 
formula. Generally, it is estimated that beyond $10 \%$ thickness of the cell, the measurement is biased by the intracellular part, which might be modified by the indentation, and potentially the sub strate properties [62]. In our case, this thickness corresponds to the height of the bacteria with a maximum value around $700 \mathrm{~nm}$ (see below). Consequently, the adjustments made during this work were performed on a maximum distance of $70 \mathrm{~nm}$, though it may also be suitable on a longer distance for some samples. This also limits the effect of the Hertz model assumptions concerning a purely homogeneous, linearly elastic material and an infinite sam ple thickness.

\subsection{Statistical description of AFM data}

To determine if statistical variations were present between untreated and treated bacteria (either with $\mathrm{SiO}_{2} \mathrm{NPs} 100 \mathrm{~nm}$ or $\mathrm{SiO}_{2} \mathrm{NPs} 4 \mathrm{~nm}$ ), the Mood's median test, which establishes the equality between medians of independent samples, has been applied to our data. This test was chosen because it is insensitive to exceptional values and does not depend on the distribution shape and variance. If $X^{2} \geq X^{2} \alpha_{\text {, }(n-1)}$ then the null hypothesis is rejected: the $n$ samples are significantly different, at a significant level of $\alpha \%$. In our case, $\alpha=5 \%$ and $n=2$. In addition, the Shapiro Wilk test was performed to assess the matching between the Young modulus distributions of treated and untreated bacteria with a normal distribution. Such a test may also be represented with a Q Q plot. The test is significant if the null hypothesis is rejected, $\mathrm{p}<\alpha=5 \%$, which means data do not follow a normal dis tribution. Oppositely, if the null hypothesis is accepted, $p>\alpha=5 \%$, it does not mean the data follow a normal distribution. Then, to characterize in more details the potential differences obtained on the Young modulus distribution of untreated and treated bacteria, we calculated the skewness, $b_{1}$, which allows to determine the importance of the asymmetry in a distribution: $b_{1} \frac{m_{3}}{s^{3}}$

where $m_{3}$ is the sample third central moment and $s$ is the sample standard deviation.

If $b_{1}=0$ the distribution is symmetric. If $b_{1}>0$, the distribution is left dissymmetric whereas if $b_{1}<0$, the distribution is right dissymmetric.

\section{Results}

\subsection{Untreated E. coli: Soft rod like cells}

Fixed on a PEM and imaged in ultrapure water, E. coli cells form films, more or less dense depending on the rinsing step (Fig. 1a and b). They have the typical well known rod shape, previously observed in air and liquid [63] (Fig. 1c and d). Their length and width are similar to those estimated in air, around $2 \mu \mathrm{m}$ and 1 $\mu \mathrm{m}$ respectively. Because of their hydrated state, the only differ ence lies in their height: $700 \mathrm{~nm}$ at maximum, corresponding to about twice as much as the estimated height for $E$. coli observed in air. Such characteristics, in agreement with previous studies [63], are representative of healthy bacteria. Noteworthy is the more homogeneous aspect (still rough and irregular) of the E. coli surface in liquid (Fig. 1c) in comparison to the ripples structure, observed in air and characterized by a specific relief associated to the presence of LPS in its OM (Fig. 1d) [59]. This phenomenon is likely due to the hydration state of the OM allowing a more or less significant extension of LPS, even if a screening effect due to the liquid environment cannot be excluded.

To achieve the mechanical study of $E$. coli surface, FCs were per formed on highly aggregated cells as well as more isolated ones. As expected, during the approach, FCs performed on the central part of $E$. coli cells exhibit the specific features of those obtained with a)

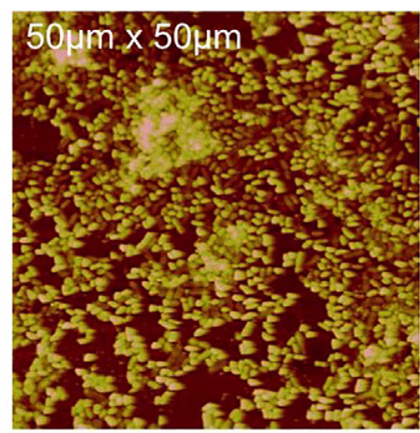

c)

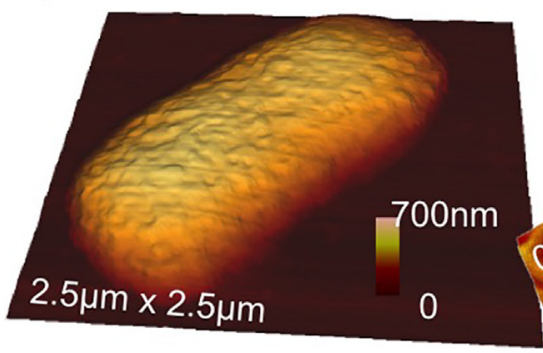

b)

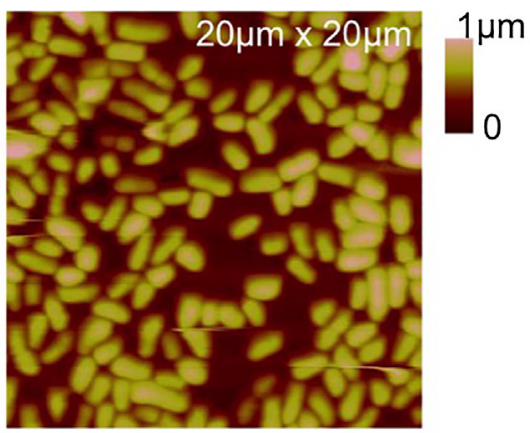

d)

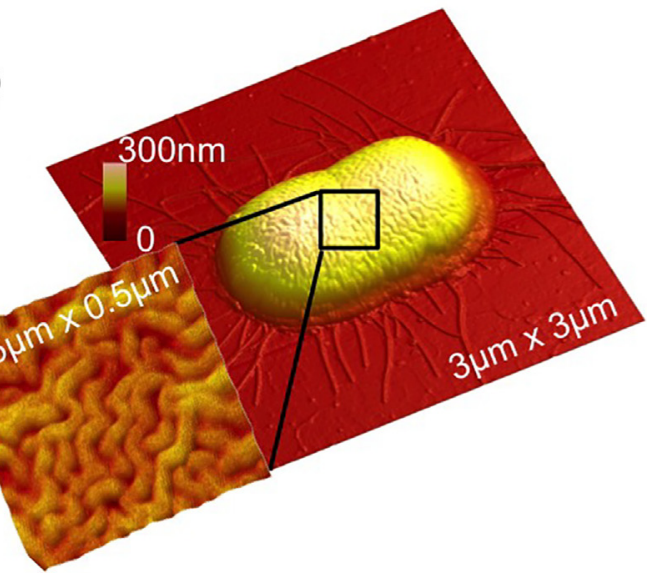

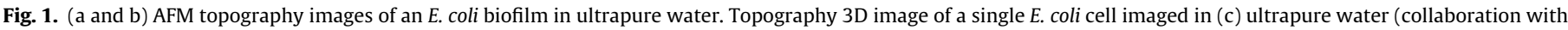
JPK instruments) and (d) in air (reprinted with permission from Ref. [17]). A magnified view of E. coli surface, observed in air, is also shown in (d). 
a soft sample (Fig. 2a): a baseline (I) in the absence of interaction, a linear part (III) following the repulsive interactions between the tip and the sample and, in between, a nonlinear zone (II) due to the indentation of the sample. Such a response is very different from the substrate one. Indeed, due to the very small thickness of the PEM (average thickness of $4 \mathrm{~nm}$ ), the FC obtained on this layer exhibit the typical behavior of stiff material (abrupt increase in the deflection signal after contact) such as the mica substrate underneath: no indentation is observed at the observation scale (Fig. 2a and b). To account for any artifact due to the curvature of $E$. coli, we also performed FCs in various areas of the same cell (data not shown). Qualitatively, results show similar features, as described above, implying a global homogeneous soft structure of the bacteria, regardless of the scanned zone. Discrepancies between bacteria are also observed, in the non linear and linear parts, confirming other studies based on force mapping of bacteria $[41,64]$. They are likely due to different molecular organizations and/or compositions leading to stiffer and softer domains present in the cell wall, which involve different mechanical responses between peripheral and apical regions [65,66]. These observations justify our choice to perform FCs only in the central region of the cell; this also prevents any artifact due to edge effect of both cell and tip. Among various experimental sets of E. coli and exploring different zones (highly aggregated cells to more isolated ones), bacteria showed an overall homogeneity in their response (Fig. 2c).

Quantitatively, we calculated the Young modulus of about 30 bacteria over 4 experimental sets (i.e. independent samples from different bacterial cultures), by adjusting their FC with the Hertz model, according to the procedure described in the Materials and
Methods. In one experimental set, the Young modulus can vary by one order of magnitude. The apparently slight discrepancies observed on the curves turn out to hide a relatively high dispersity in the elasticity of the cells (Fig. 2d). Such a heterogeneity is also highlighted among the different experimental sets of bacteria. These results reflect the limitations associated with live cell exper iments, where the intrinsic mechanical behavior is potentially influenced by the physiological state of cells $[64,67]$ or their adhe sion to the substrate $[68,69]$. A median value for the Young modu lus of $E$. coli was estimated to be $1.2 \mathrm{MPa}$, corresponding to a stiffness of $0.05 \mathrm{~N} / \mathrm{m}$. The interquartile range (1st quartile/3rd quartile) is [0.5, 2.3 MPa] (Fig. 2d inset).

This is in good agreement with previous studies on $E$. coli (Table 1). The observed differences can be ascribed to the diverse methods used in immobilizing bacteria that lead to different adhe sion forces between cells and substrate [70] or to different solvents and therefore different osmotic and turgor pressures: the higher the turgor pressure the higher the stiffness [39,71].

\subsection{Morphology of E. coli treated with $\mathrm{SiO}_{2} \mathrm{NPS}$}

In a previous work, we showed the existence of a critical diam eter, below which $\mathrm{SiO}_{2}$ NPs are toxic for E. coli: $50 \mathrm{~nm}<\Phi c<80$ $\mathrm{nm}$ [17]. Above this diameter, NPs do not change the overall mor phology of $E$. coli or its membrane structure. On the opposite, below this diameter, NPs induce (i) a transition from a rod to a more spherical shape (Fig. 3a), (ii) the formation of pore like lesions/membrane invaginations (arrows in Fig. 3a) and (iii) the reorganization of the LPS molecules of the OM of $E$. coli from

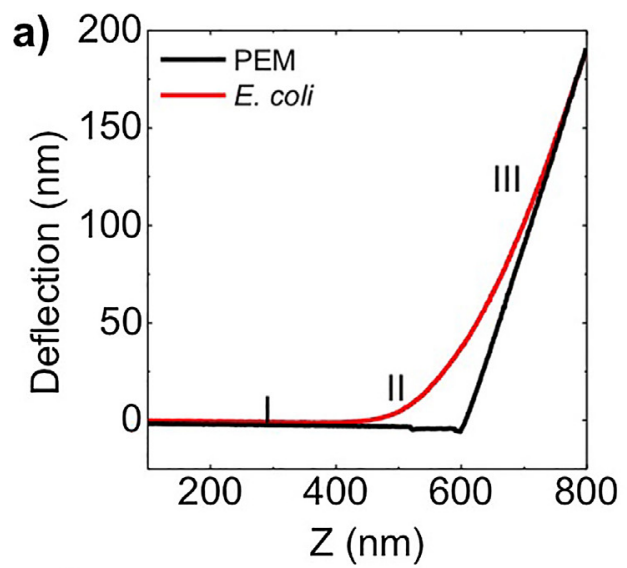

b)

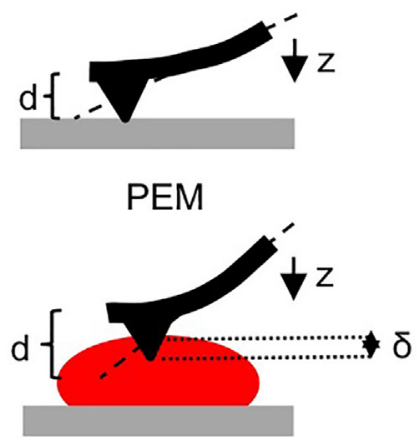

E. coli on PEM
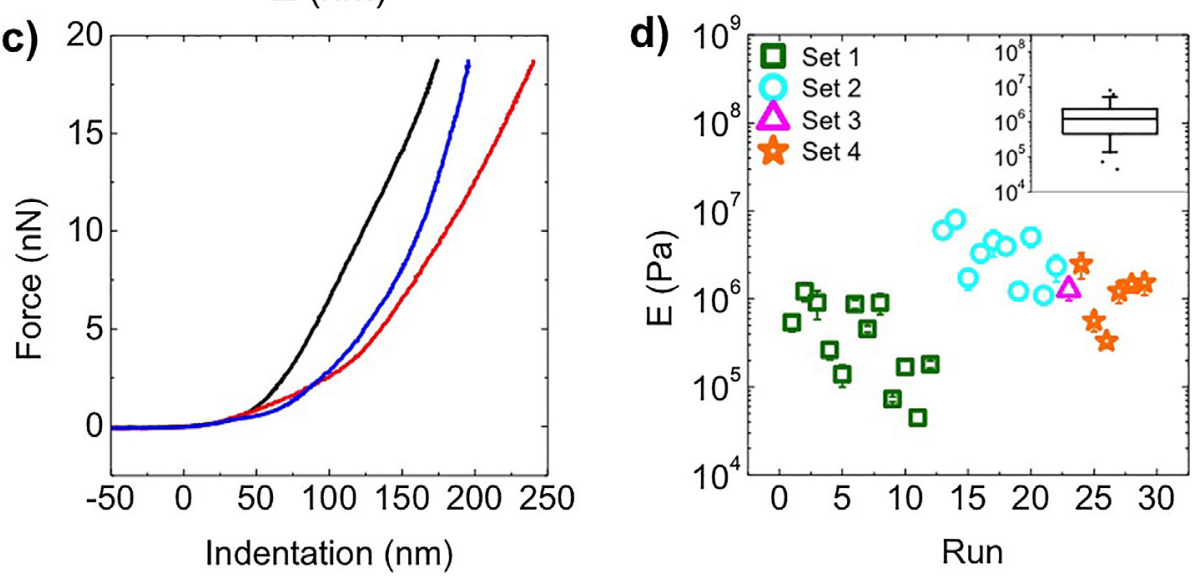

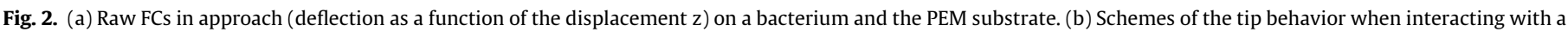

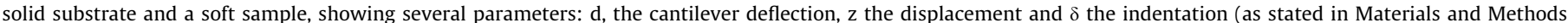

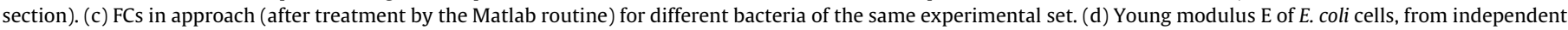

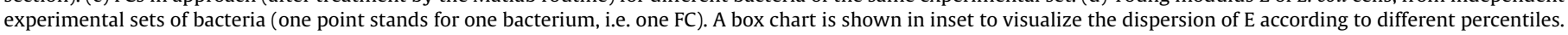


Table 1

Comparison of the constant of stiffness, $\mathrm{k}_{\mathrm{s}}$, of $E$. coli found in the literature.

\begin{tabular}{llll}
\hline Fixation & Solvant & $\mathrm{k}_{\mathrm{S}}(\mathrm{N} / \mathrm{m})$ & Ref. \\
\hline Polyelectrolytes & Water & $0.05 \pm 0.01$ & This work \\
Poly-L-lysine & Water & $0.04 \pm 0.01$ & {$[36]$} \\
Glutaraldehyde & Buffer & 0.194 & {$[72]$} \\
Glutaraldehyde & Buffer & $0.23 \pm 0.01$ & {$[73]$} \\
EDC/NHS & Buffer & $0.10 \pm 0.01$ & {$[73]$} \\
EDC/NHS & Tris buffer & $0.044 \pm 0.014$ & {$[74]$} \\
Glutaraldehyde & Tris buffer & $0.13 \pm 0.01$ & {$[74]$} \\
\hline
\end{tabular}

extended ripples to more aggregated ones (Fig. $3 \mathrm{~b}$ to be compared to Fig. 1d). Such effects seem to illustrate the disruption of $E$. coli OM through breaks into the LPS organization and the destructura tion of its peptidoglycan layer involved in the cell shape. Eventu ally, cell lysis and subsequent leakage of intracellular components might occur (Fig. 3c)

\subsection{Change in E. coli elasticity after interaction with $\mathrm{SiO}_{2} \mathrm{NPS}$}

Taking into account the existence of this NP critical diameter with respect to NPs antibacterial activity, we will focus here on the effect of two $\mathrm{SiO}_{2}$ NPs with diameters well below and well above $\Phi c$, on the bacterial membrane properties, at the submicro metric scale.

$\Phi$ > Фc: case of $\mathrm{SiO}_{\mathbf{2}}$-NPs $\mathbf{1 0 0} \mathbf{~ n m ~ - ~ F i g . ~ 4 a ~ s h o w s ~ t y p i c a l ~ F C s ~}$ obtained on E. coli cells treated by $\mathrm{SiO}_{2} \mathrm{NPs} 100 \mathrm{~nm}$. In most cases, FCs exhibit the same features as those obtained with untreated E. coli. The non linear transition which is due to the membrane elasticity can exhibit a more or less important width. At the same time, the linear part presents a more or less steep slope. However, FCs obtained following such treatment by $\mathrm{SiO}_{2} \mathrm{NPs} 100 \mathrm{~nm}$ are often included in the area of the heterogeneous responses of untreated bacteria (Fig. 4a dashed area).

Like in the case of untreated $E$. coli, dispersity is observed in the Young modulus of treated cells (Fig. 4b). The estimated median elastic modulus of $1.4 \mathrm{MPa}$, corresponding to a stiffness of 0.06 $\mathrm{N} / \mathrm{m}$, suggests that no significant difference exists between these treated $E$. coli and the healthy ones (Mood's test: $X^{2} \leq X_{0.05,1}^{2}$ ). Nev ertheless, the interquartile range (Q1 1st quartile/Q3 3rd quartile) of [1.1, 3.3 MPa] shows that there is a slight shift towards a higher value of the Young modulus.

$\Phi$ < $\boldsymbol{\Phi c :}$ case of $\mathbf{S i O}_{\mathbf{2}}$-NPs $\mathbf{4} \mathbf{n m}$ - Treatment of $E$. coli cells using $\mathrm{SiO}_{2}$ NPs $4 \mathrm{~nm}$ eventually triggers the morphological transition from a rod shape to a spherical one (Figs. $3 a$ and $5 a$ ). Such a treat ment also induces the formation of an unusual homogeneous and porous film on the substrate (Fig. 5a arrows), which will be described afterwards.

On Fig. 5a and b, bacterium (1) shows a height (530 nm) similar to those observed in healthy bacteria though it exhibits a spherical shape. In contrast, bacterium (2) has a lower height section $(270 \mathrm{~nm})$, suggesting its collapse, while it exhibits the expected rod shape. Consequently, treated bacteria can not only exhibit a different shape but also a different height, characteristics that are not necessarily correlated for all cells. For both bacteria FCs have features mainly typical of those obtained with a soft sample with different indentations (Fig. 5c). More specifically, the FC on the "spherical" bacterium (1) indicates a higher rigidity than that of

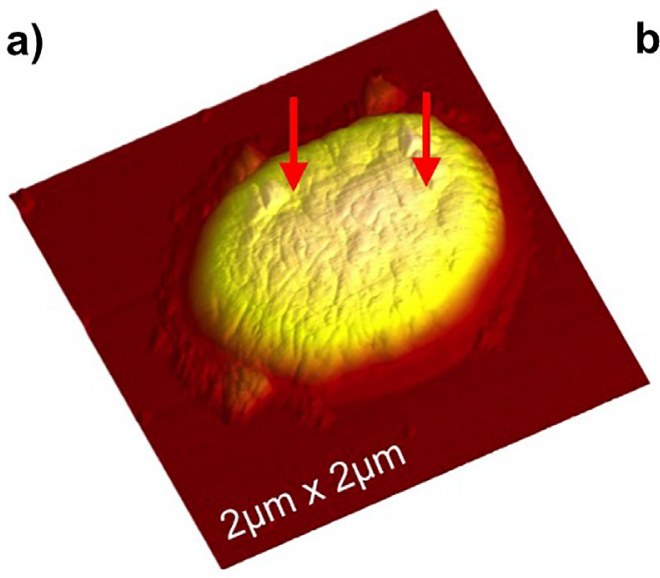

b)
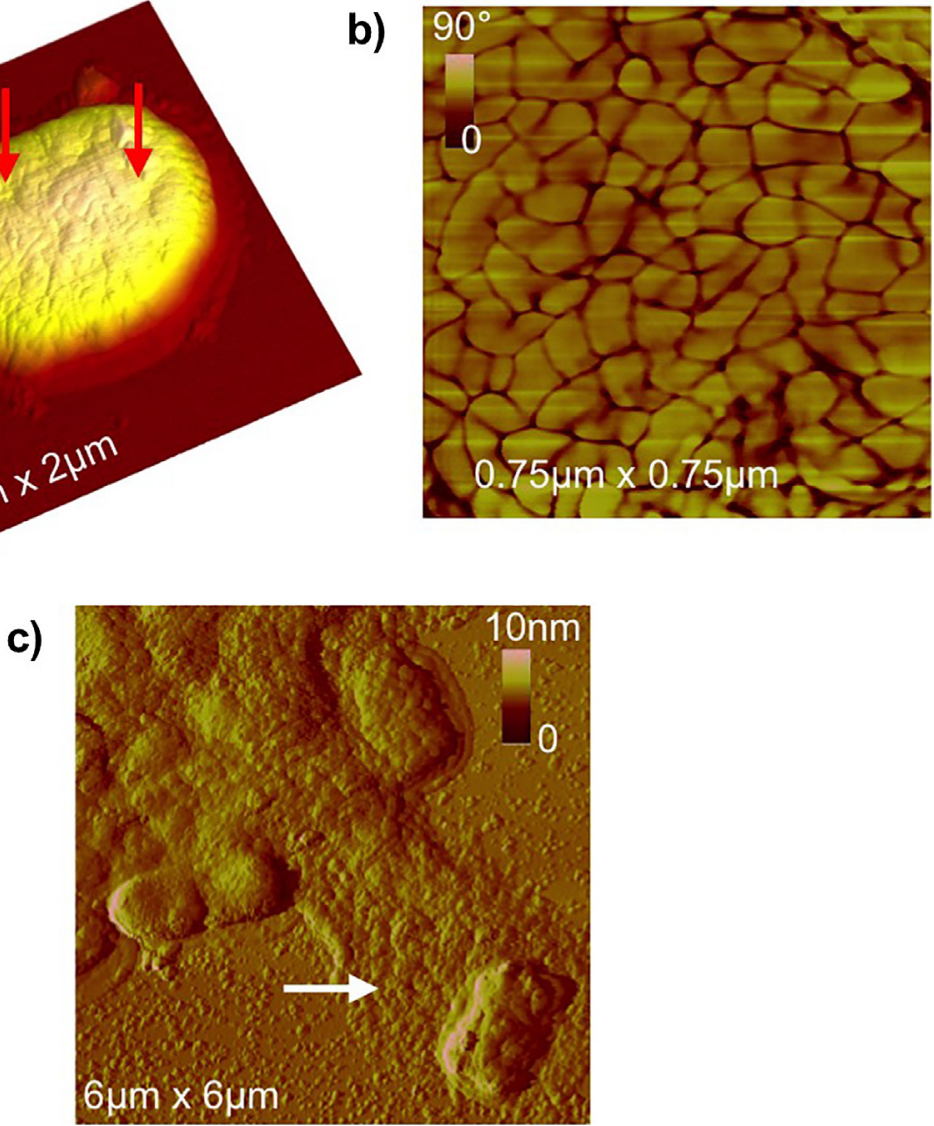

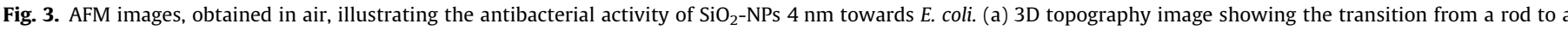

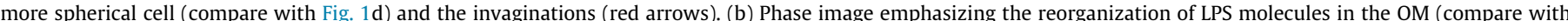

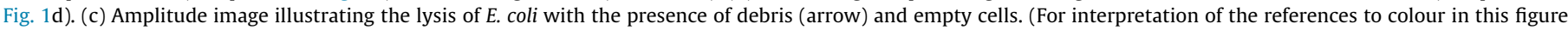
legend, the reader is referred to the web version of this article.) 

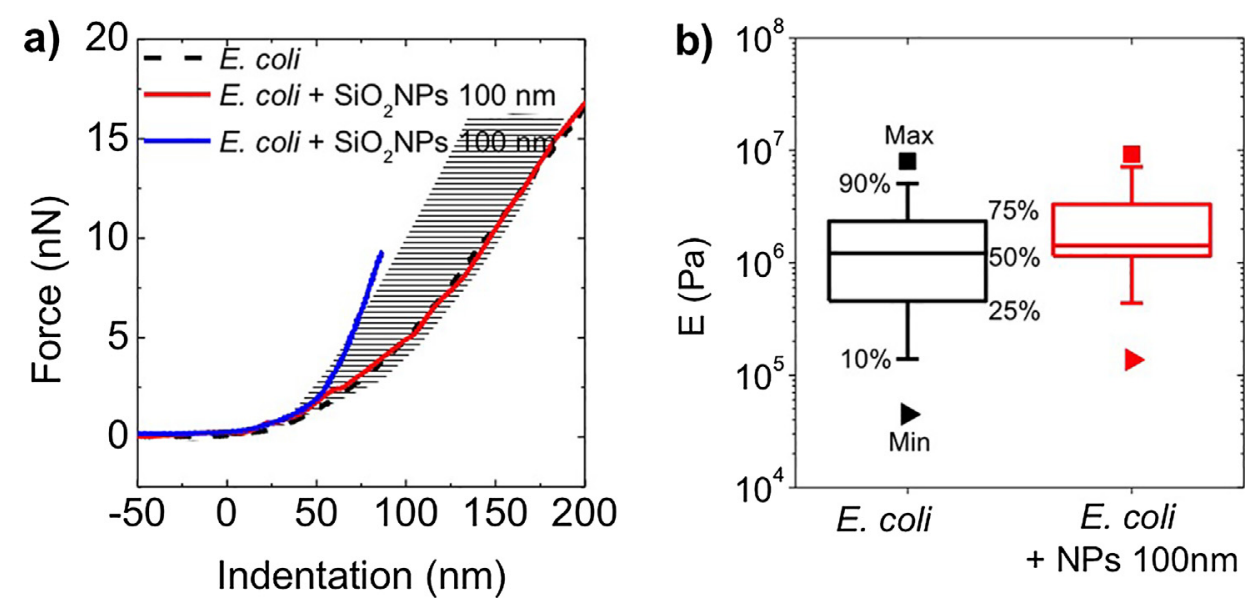

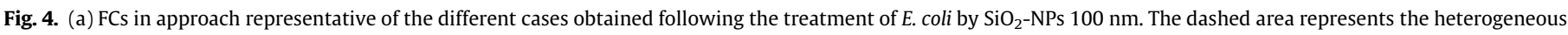

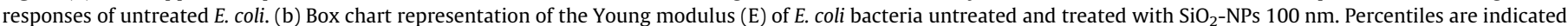
in the case of $E$. coli and are the same for treated cells.

a)
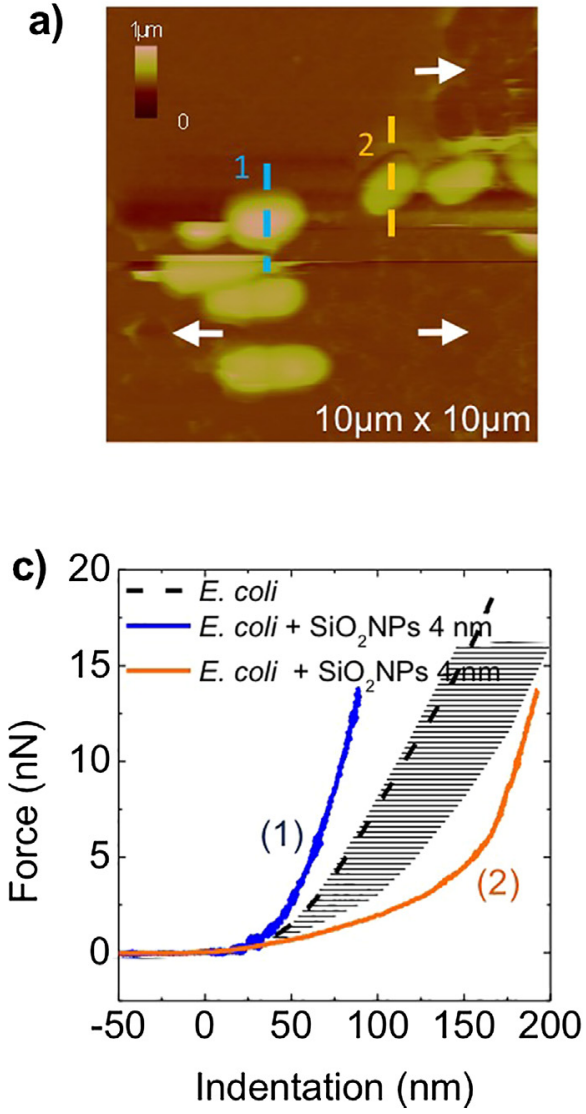
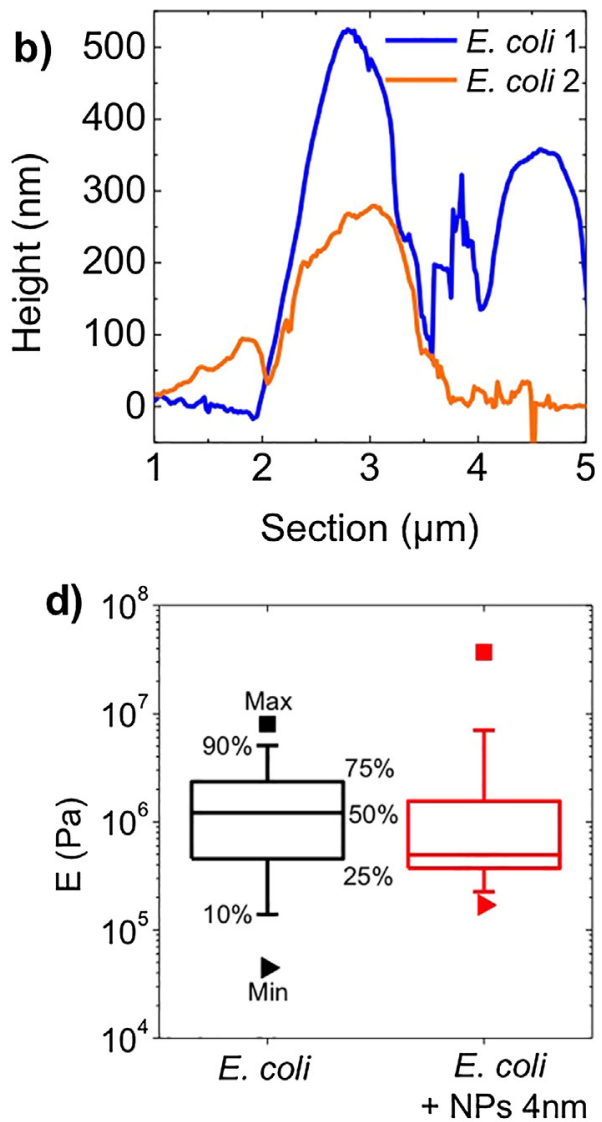

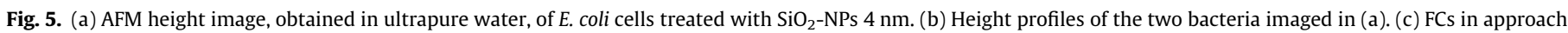

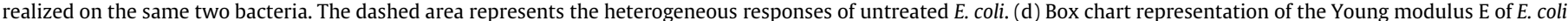
bacteria untreated and treated with $\mathrm{SiO}_{2}-\mathrm{NPs} 4 \mathrm{~nm}$. Percentiles are indicated in the case of $E$. coli and are the same for treated cells.

untreated bacteria, with an elastic modulus of $7 \mathrm{MPa}$. On the other hand, the FC on the collapsed bacterium (2) exhibits a softer behav ior with a Young modulus of $0.4 \mathrm{MPa}$, which is in favor of an alter ation of its membrane integrity.

Statistics performed on other bacteria exhibiting similar FCs show that, again, a large dispersity is obtained for $E$. coli elasticity (Fig. 5d). The estimated median elastic modulus of $0.5 \mathrm{MPa}$, corre sponding to a stiffness of $0.02 \mathrm{~N} / \mathrm{m}$, suggests that $\mathrm{SiO}_{2} \mathrm{NPs} 4 \mathrm{~nm}$ induce a significant increase in the elasticity of bacteria (Mood's test: $\left.X^{2} \geq X_{0.05,1}^{2}\right)$. Also, the interquartile range (Q1 Q3) of [0.4, 1.6 MPa] shows that there is a shift towards the lowest values of the Young modulus, while the extreme values (minimal and maximal) are higher by one order of magnitude than in the case of untreated cells. 


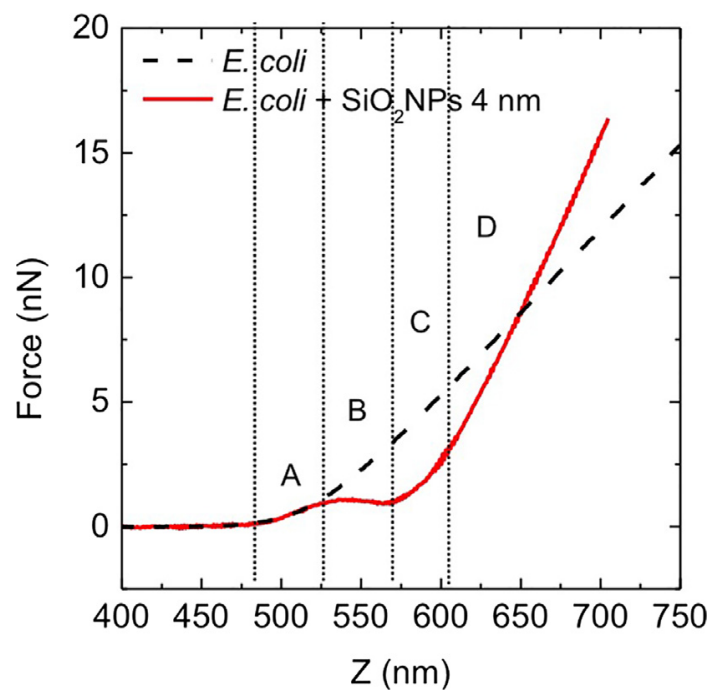

Fig. 6. Comparison of FCs performed on healthy E. coli and on those treated with $\mathrm{SiO}_{2}$-NPs $4 \mathrm{~nm}$ bearing a degraded envelope.

Moreover, in a few cases, FCs exhibited a three stage trend: (i) a non linear zone characteristic of a soft sample, (ii) a plateau over a few tens of nanometers where the deflection is null and the force constant, and (iii) a linear part (Fig. 6). This particular FC is associ ated with a collapsed bacterium, similar to bacterium (2) in Fig. 5. As untreated bacteria did not show such a behavior, it could be explained by the effect of $\mathrm{SiO}_{2} \mathrm{NPs} 4 \mathrm{~nm}$ on the organization of the bacterial envelope and its subsequent degradation. A hypothet ical scheme, explaining such a FC, is presented thereafter. First (A), the tip indents the bacterium surface with an elastic behavior. Only an elastic deformation occurs, without any perforation. At some point (B), it encounters a structure/defect within the bacterial envelope where it slides and penetrates without any resistance, resulting in a null deflection. Finally, once this damaged structure is crossed, the tip probes again the local elastic properties of the bacterium (C) coupled with the properties of the substrate (D).

This particular profile highly suggests that $\mathrm{SiO}_{2} \mathrm{NPs} 4 \mathrm{~nm}$ induce a structural modification of the bacterial envelope, or even of the plasma membrane, and supports a transition in the organi zation of LPS and membrane invaginations already observed in air (Fig. 3). Furthermore, the higher slope of the linear part (D) is also in favor of cell flattening and degradation, as the tip responds to a greater extent and earlier to the substrate than for healthy untreated E. coli.

Finally, the treatment of $E$. coli with $\mathrm{SiO}_{2} \mathrm{NPs} 4 \mathrm{~nm}$ also induces on the substrate the formation of an unusual homogeneous and porous film, called bacterial "fingerprints" later on, besides the expected dense film (Fig. 7a). These "fingerprints" lower than the PEM substrate are encircled by an accumulation of materials (arrows in Fig. 7a) with thickness from tens to about one hundred nanometers (Fig. 7b). Given the height profiles of the borders, it is unlikely that this material is made of NPs. Also, as the entire area is not covered by this accumulation, polyelectrolytes are probably not involved since they rather should be homogeneously dis tributed on the substrate due to the spin coating deposition. In a)
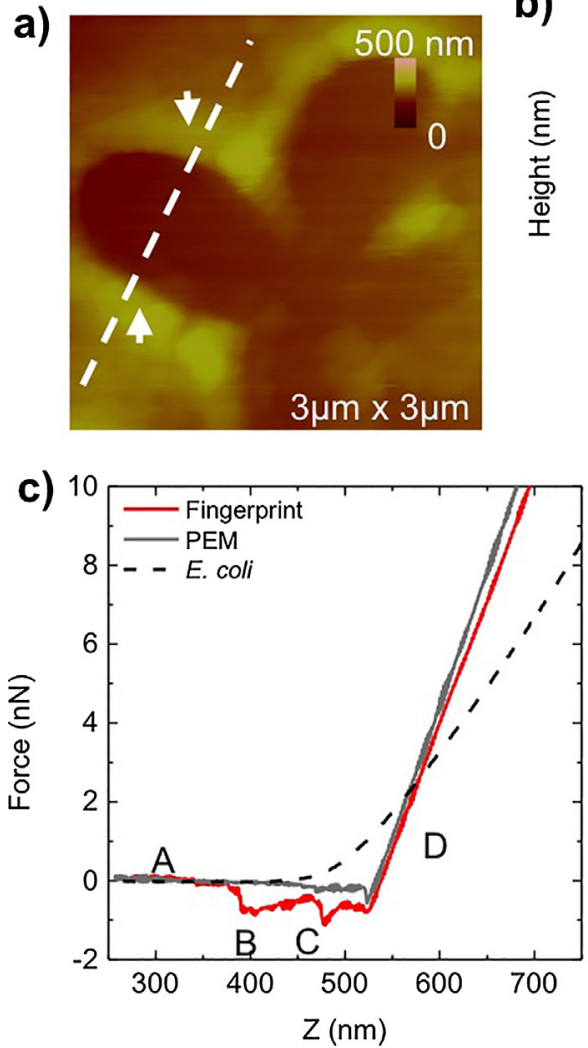

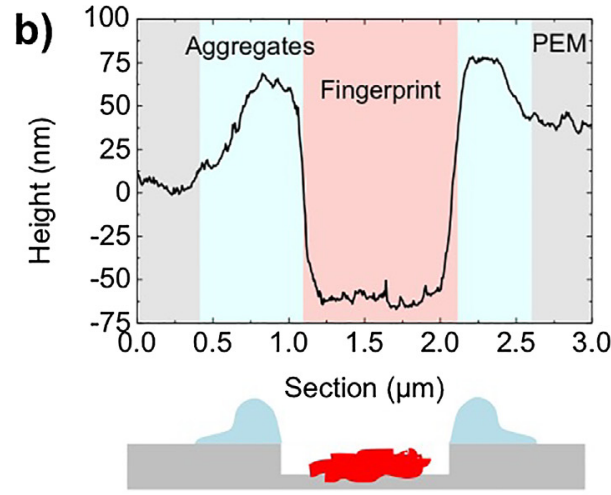

d)

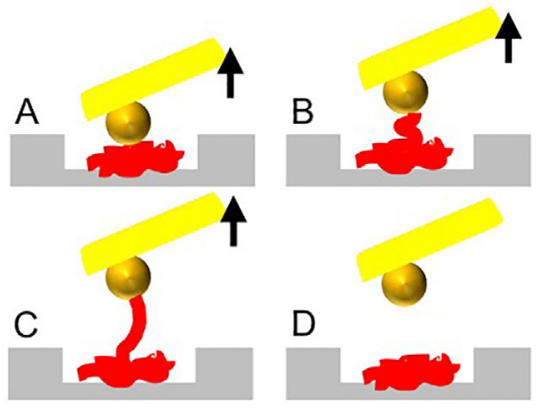

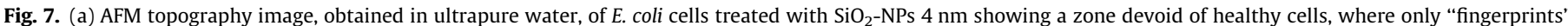

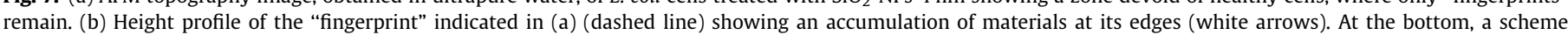

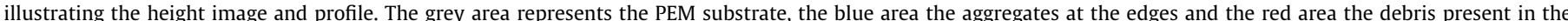

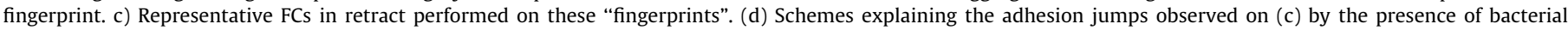
residues within the "fingerprints". (For interpretation of the references to colour in this figure legend, the reader is referred to the web version of this article.) 
a)
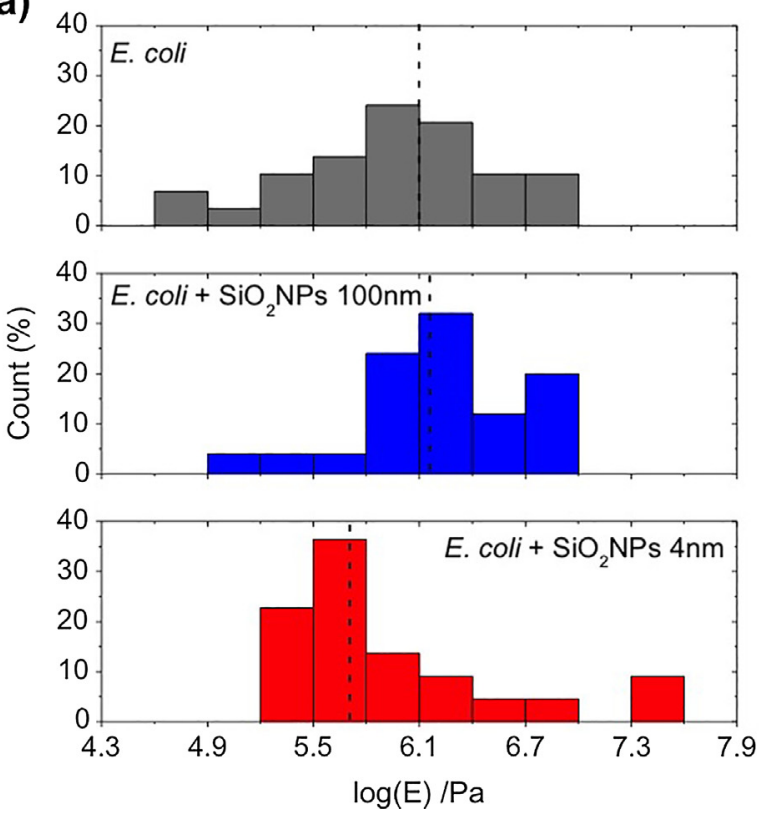

b) $\quad$ Data
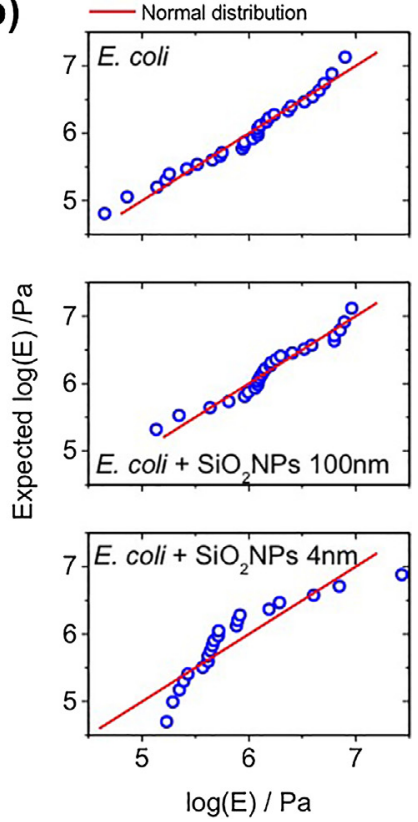

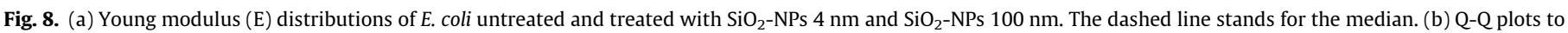
compare the three distributions obtained in (a) to a normal distribution.

addition, areas inside the "fingerprints", close by and far from the edges show different interactions with the AFM tip, as emphasized by friction images (data not shown). Consequently, these three areas (Fig. 7a and b) are probably made of diverse materials orga nized differently explaining different mechanical properties.

FCs realized on the bacterial "fingerprints" exhibit different types of behavior with typical ones presented in Fig. 7c: (i) a base line (almost zero deflection) followed by a purely linear part with a slope close to 1, as for the PEM film (grey curve). This baseline shows many discrepancies: contrary to the PEM substrate, "jumps" in force are observed, which are more or less wide and numerous (red curve). These phenomena reveal the presence of a structure generating adhesion events attracting the tip to the sample. Such an adhesion could be due to the presence of crosslinked cell debris within these "fingerprints"; these debris act like "glue" by attach ing to the tip and induce a negative cantilever deflection despite the sample removal (Fig. 7d). Combined with the morphological study, these results confirm the toxicity of $\mathrm{SiO}_{2} \mathrm{NPs} 4 \mathrm{~nm}$ towards E. coli and strongly argue in favor of their potential bacteriolytic activity towards some cells in the bacterial population.

Though they deeply illustrate and enlighten the interaction between $E$. coli and $\mathrm{SiO}_{2} \mathrm{NPs} 4 \mathrm{~nm}$, FCs showing uncommon fea tures (different from those of soft samples) (Figs. 6 and 7) could not be processed by the Matlab routine and, as a consequence, the Young modulus was not calculated in these cases.

\subsection{Comparative analysis}

The set of results obtained on E. coli exposed or not to $\mathrm{SiO}_{2} \mathrm{NPs}$ is shown in Fig. 8a. These histograms allow an easier overview and comparison between the elasticity of the untreated and treated E. coli, than the unique values of medians reported above.

As seen above, whatever the treatment, the distribution of the Young modulus (in $\log$ ) is relatively wide, probably due to the intrinsic inhomogeneity of the cellular population. Indeed, cells are probably not in the same growth stage as bacteria are not syn chronously dividing. Nonetheless, depending on the NPs treat ment, different shapes in the Young modulus distributions can be observed, which are compared to a normal distribution in Fig. 8b. As long as the treatment by $\mathrm{SiO}_{2} \mathrm{NPs} 100 \mathrm{~nm}$ is concerned, accord ing to the Shapiro Wilk test, both untreated and treated E. coli might follow a normal distribution. Another way to characterize such distributions is the $\mathrm{Q}$ Q plot, which is a graphical method to compare distributions by plotting their quantiles against each other (Fig. 8b). In each case, the Q Q plot does not follow the $45^{\circ}$ line $\mathrm{y}=\mathrm{x}$ (slight inflection points are observed), suggesting that the distributions obtained for E. coli and E. coli treated with $\mathrm{SiO}_{2} \mathrm{NPs} 100 \mathrm{~nm}$ do not actually follow the normal distribution. Indeed, the calculated skewness of 0.5 and 0.4 respectively, confirm that these distributions are not symmetric and, conse quently, are not equal to a normal distribution. In addition, the distribution obtained on $E$. coli treated with $\mathrm{SiO}_{2} \mathrm{NPs} 100 \mathrm{~nm}$ con firms the shift towards the highest Young modulus, previously observed on the box chart (Fig. 4b). Bins of low Young modulus val ues are depopulated $(\mathrm{Q} 1=0.5 \mathrm{MPa}$ for untreated cells vs $\mathrm{Q} 1=1.1$ MPa for treated cells) while bins of high Young modulus are equally populated $(\mathrm{Q} 3=2.3 \mathrm{MPa}$ for untreated cells vs $\mathrm{Q} 3=3.3$ $\mathrm{MPa}$ for treated cells). Despite this shift, $\mathrm{SiO}_{2} \mathrm{NPs} 100 \mathrm{~nm}$ do not seem to have a major impact on the stiffness of $E$. coli (equivalent median), in agreement with their harmless effect on the cell mor phology and membrane structure.

As long as the treatment by $\mathrm{SiO}_{2} \mathrm{NPs} 4 \mathrm{~nm}$ is concerned, the Shapiro Wilk test and the Q Q plot both show that the distribution is far from following a normal distribution. A skewness as high as 1.5 confirms a significant shift towards the lowest value of the Young modulus, as observed in the box chart (Fig. 5d). Then, such a treatment induces the opposite effect of that observed for $\mathrm{SiO}_{2} \mathrm{NPs} 100 \mathrm{~nm}(\mathrm{Q} 1=0.4 \mathrm{MPa}, \mathrm{Q} 3=1.6 \mathrm{MPa}) . \mathrm{SiO}_{2} \mathrm{NPs} 4 \mathrm{~nm}$ induced a significant decrease in cell elasticity, in good agreement with the morphological and membrane damage previously shown [17].

\section{Discussion}

Our study aims are not only to correlate the morphological changes observed after NPs treatment to the mechanical properties 
of these structures, but also to quantify the mechanical interac tions involved in these processes. The case of $\mathrm{SiO}_{2} \mathrm{NPs} 100 \mathrm{~nm}$ will not be discussed thereafter because no significant modifications, neither on the morphology nor on the elasticity of cells, were observed, implying their harmless behavior towards $E$. coli.

We will then focus on the case of $\mathrm{SiO}_{2} \mathrm{NPs} 4 \mathrm{~nm}$ treatment. Among the previous studies involving mechanical properties of bacteria, most of them were dealing with the effect of antibacterial compounds, and provided elements to emit hypotheses on the bac tericidal action of $\mathrm{SiO}_{2} \mathrm{NPs} 4 \mathrm{~nm}$. First, a significant decrease in the Young modulus of E. coli has been shown. Such a decrease was also reported upon treatment with chitosan and lysostaphin (enzyme degrading peptidoglycan) on Staphylococcus aureus [75,76]. In this study, the decrease in stiffness was correlated with a global weak ening of the cell wall, potentially accompanied by cell lysis. Despite a different mechanism of action, $\beta$ lactam and aminoglycoside also led to the disruption of the peptidoglycan layer and a decrease of the Young modulus of Pseudomonas aeruginosa cells [77]. Other detailed studies on the action of antimicrobial peptides also corre lated such a decrease in cell elasticity with cell envelope modifica tions associated with higher surface roughness, cell flattening and pore formation [78 80]. Indeed, Quiles et al. made the link between the decrease in Pseudomonas fluorescens elasticity and the permeabilization of the bacterial membrane after the action of a linear cationic peptide [80]. All these cases are relevant to organic and biochemical molecules, and to our knowledge it is the first time that such a quantitative study on bacteria exposed to such small size metal oxide NPs is undertaken. In a previous paper silver NPs were twice as big [81]. We also outline and quan tify, in this work, the similar damages induced by tiny nanoparti cles when interacting with bacteria. Indeed, in the case of $\mathrm{SiO}_{2}$ NPs $4 \mathrm{~nm}$, it is reasonable to assume that the decrease in Young modulus in E. coli is associated to the modifications of, at least, the envelope structure because the NPs are small enough to inter act deeply with the outer membrane.

Moreover, these NPs also generate important morphological and membrane damages (Figs. 3 and 6). Cell lysis is further emphasized by the residual structures, "fingerprints" that have similar width and length as untreated bacteria and exhibit edges of tens to hun dred nanometers in height, probably bacterial residues. To our knowledge, such "fingerprints" have been reported only a couple of times, notably in the study of the antimicrobial peptide PGLa action on E. coli [78] and the work on E. coli incubation in egg white at bactericidal temperature [82]. Adhesion events observed in these "fingerprints" show evidence of lysis debris still attached to the sub strate resulting from the rupture and the loss of cytoplasm materi als. Previous studies on the interaction between diverse biolayers and substrates reported such adhesion events on FCs: desorption forces were estimated around $40200 \mathrm{pN}$ for polyelectrolytes depending on their chain length and concentration [83], and between 10 and $100 \mathrm{pN}$ for peptides depending on the substrate functionalization [84]. In our case, we estimated a desorption force around $500 \mathrm{pN}$ to $1 \mathrm{nN}$. These high values are likely the result of a "mixture" of complex composition including polylectrolytes, lipids and proteins of bacterial membranes. In particular, the diversity of lipids in terms of chain lengths and polar head group composition probably explains the higher desorption forces determined here. Finally, the very rare studies exploring the elastic modification of bacteria following their treatment with bactericidal silver NPs also underlined a decrease in the Young modulus caused by extensive damage to the cell membrane (composition and structure) [81].

In summary, the previous studies on bio organic molecule impacts and our results strengthen the idea that $\mathrm{SiO}_{2} \mathrm{NPs} 4 \mathrm{~nm}$, as organic species, probably interact with $E$. coli according to the following mechanism. First, likely due do to their small size and chemical nature, they induce a disorganization in the close packing of the LPS molecules, and change the surface structure of E. coli (Fig. 3b). Doing so, they induce the formation of pore like lesions in the OM (Figs. 3a and 6), which is then permeabilized and the peptidoglycan potentially compromised. This probably induces a transition from a rod to a spherical shape (Fig. 5a) and an increase in the cell wall elasticity (Fig. 5d). Finally, as a direct or indirect consequence of their presence, a cell lysis occurs and cytoplasmic elements are released (Figs. $3 c$ and 7 ). Though this hypothetical mechanism is proposed, many questions remain and still need to be addressed, especially in the chronology of the observed dam ages. In addition, heterogeneous responses were observed after treatment with $\mathrm{SiO}_{2} \mathrm{NPs} 4 \mathrm{~nm}$, among others high values of the Young modulus. They could find their origin in the potential change of the cell shape without being associated to the cell flat tening, leading to higher surface tension.

\section{Conclusion}

Many studies have focused on the well known antibacterial activity of metal oxide and silver NPs, coping with the charge and size dependency of their interactions without addressing their impact on the mechanical properties of cells [16,28,81]. In our pre vious work, we had shown the existence of a critical diameter (50 $\mathrm{nm}<\Phi_{\mathrm{c}}<80 \mathrm{~nm}$ ) below which $\mathrm{SiO}_{2}$ NPs induce morphological and membrane structural damages eventually leading to the E. coli cell lysis [17]. Here, by combining AFM imaging with spec troscopy mode, we also quantitatively demonstrate that such a toxicity is statistically correlated with modifications in the $E$. coli elasticity. Indeed, as opposed to $\mathrm{SiO}_{2} \mathrm{NPs} 100 \mathrm{~nm}$ which do not have a major impact on the cell elasticity, the $\mathrm{SiO}_{2} \mathrm{NPs} 4 \mathrm{~nm}$ do induce a significant decrease in the cell Young modulus. This, along with the morphological study, provides clues to the $\mathrm{SiO}_{2} \mathrm{NPs}$ potential bactericidal mechanism of action: by first damaging the bacterial OM (LPS re organization, invaginations of the envelope), such small NPs induce the destructuration of the peptidoglycan layer and, subsequently, lead to the cell lysis. Such a statistical analysis and a mechanical quantification of the NPs/bacteria inter action has only been reported once, for metallic silver NPs twice as big as those reported here [81]. In the case reported here, it should be mentioned that the study only concerns the mechanical cell/NP interaction, since no leaching of any kind is supposed to take place as in the case of $\mathrm{Ag}^{+}$for silver nanoparticles.

Up to now, interactions between bacteria and $\mathrm{SiO}_{2}$ NPs have not been well documented although such NPs are considered as promising tools for diverse biomedical applications, including antibacterial agent, because of their harmless behavior towards eucaryotic cells and their easy surface modifications [21,55]. Con sequently, we have, here, addressed the intrinsic effects of $\mathrm{SiO}_{2}$ NPs on E. coli membrane, from both morphological and mechanical points of view. Other parameters, like the charge and shape of NPs, play a critical role in their deleterious impact on cells [13]. They should now be investigated in light of the great promise offered by the combination of AFM imaging and spectroscopy modes, both in air and in liquid.

\section{Acknowledgment}

The authors thank the Région Aquitaine and CNRS (France) for supporting this work through the equipment of the NanoSpectrol magerie (NSI LOMA) platform used in this work (CPER COLA2). They are grateful to the Direction Générale de l'Armement (DGA, Ministère de la Défense, France), the Région Aquitaine (France) and LOMA for their financial support through the Ph.D. grant of M. Mathelié Guinlet. Finally, authors thank NSI LOMA platform and the JPK Instruments Company (Berlin, Germany) for technical 
and experimental help and $\mathrm{H}$. Saadaoui for his helpful advises and discussions about AFM mechanical measurements.

\section{References}

[1] R. Duncan, R. Gaspar, Nanomedicine(s) under the microscope, Mol. Pharm. 8 (2011) 2101-2141, https://doi.org/10.1021/mp200394t.

[2] O.C. Farokhzad, R. Langer, Impact of nanotechnology on drug delivery, ACS Nano 3 (2009) 16-20, https://doi.org/10.1021/nn900002m.

[3] S.R. Grobmyer, D.L. Morse, B. Fletcher, L.G. Gutwein, P. Sharma, V. Krishna, S.C. Frost, B.M. Moudgil, S.C. Brown, The promise of nanotechnology for solving clinical problems in breast cancer, J. Surg. Oncol. 103 (2011) 317-325, https:// doi.org/10.1002/jso.21698.

[4] C. Buzea, I.I. Pacheco, K. Robbie, Nanomaterials and nanoparticles: Sources and toxicity, Biointerphases 2 (2007), https://doi.org/10.1116/1.2815690.

[5] A.B. Djurišić, Y.H. Leung, A. Ng, X.Y. Xu, P.K. Lee, N. Degger, Toxicity of metal oxide nanoparticles: Mechanisms, characterization, and avoiding experimental artefacts, Small 11 (2015) 26-44.

[6] N. Lewinski, V. Colvin, R. Drezek, Cytotoxicity of nanoparticles, Small 4 (2008) 26-49, https://doi.org/10.1002/smll.200700595.

[7] A. Nel, T. Xia, L. Mädler, N. Li, Toxic potential of materials at the nanolevel, Science 311 (2006) 622-627.

[8] V. Srivastava, D. Gusain, Y.C. Sharma, Critical review on the toxicity of some widely used engineered nanoparticles, Ind. Eng. Chem. Res. 54 (2015) 62096233, https://doi.org/10.1021/acs.iecr.5b01610.

[9] M. Farré, K. Gajda-Schrantz, L. Kantiani, D. Barceló, Ecotoxicity and analysis of nanomaterials in the aquatic environment, Anal. Bioanal. Chem. 393 (2009) 81-95, https://doi.org/10.1007/s00216-008-2458-1.

[10] M.A. Maurer-Jones, I.L. Gunsolus, C.J. Murphy, C.L. Haynes, Toxicity of engineered nanoparticles in the environment, Anal. Chem. 85 (2013) 30363049, https://doi.org/10.1021/ac303636s.

[11] A. Pietroiusti, A. Magrini, L. Campagnolo, New frontiers in nanotoxicology: Gut microbiota/microbiome-mediated effects of engineered nanomaterials, Toxicol. Appl. Pharmacol. 299 (2016) 90-95, https://doi.org/10.1016/ j.taap.2015.12.017.

[12] L. Rowenczyk, C. Duclairoir-Poc, M. Barreau, C. Picard, N. Hucher, N. Orange, M. Grisel, M. Feuilloley, Impact of coated TiO2-nanoparticles used in sunscreens on two representative strains of the human microbiota: Effect of the particle surface nature and aging, Colloids Surf. B Biointerfaces. 158 (2017) 339-348, https://doi.org/10.1016/j.colsurfb.2017.07.013.

[13] C.M. Beddoes, C.P. Case, W.H. Briscoe, Understanding nanoparticle cellular entry: A physicochemical perspective, Adv. Colloid Interface Sci. 218 (2015) 48-68, https://doi.org/10.1016/j.cis.2015.01.007.

[14] T.M. Tolaymat, A.M. El Badawy, A. Genaidy, K.G. Scheckel, T.P. Luxton, M. Suidan, An evidence-based environmental perspective of manufactured silver nanoparticle in syntheses and applications: A systematic review and critical appraisal of peer-reviewed scientific papers, Sci. Total Environ. 408 (2010) 999-1006, https://doi.org/10.1016/j.scitotenv.2009.11.003.

[15] T. Silva, L.R. Pokhrel, B. Dubey, T.M. Tolaymat, K.J. Maier, X. Liu, Particle size, surface charge and concentration dependent ecotoxicity of three organocoated silver nanoparticles: Comparison between general linear modelpredicted and observed toxicity, Sci. Total Environ. 468-469 (2014) 968976, https://doi.org/10.1016/j.scitotenv.2013.09.006.

[16] A. Simon-Deckers, S. Loo, M. Mayne-L'hermite, N. Herlin-Boime, N. Menguy, C. Reynaud, B. Gouget, M. Carrière, Size-, composition-and shape-dependent toxicological impact of metal oxide nanoparticles and carbon nanotubes toward bacteria, Environ. Sci. Technol. 43 (2009) 8423-8429.

[17] M. Mathelié-Guinlet, L. Béven, F. Moroté, D. Moynet, C. Grauby-Heywang, I. Gammoudi, M.-H. Delville, T. Cohen-Bouhacina, Probing the threshold of membrane damage and cytotoxicity effects induced by silica nanoparticles in Escherichia coli bacteria, Adv. Colloid Interface Sci. 245 (2017) 81-91, https:// doi.org/10.1016/j.cis.2017.04.012.

[18] I. Lynch, A. Salvati, K.A. Dawson, Protein-nanoparticle interactions: What does the cell see?, Nat Nanotechnol. 4 (2009) 546, https://doi.org/10.1038/ nnano.2009.248.

[19] G. Pyrgiotakis, C.O. Blattmann, P. Demokritou, Real-time nanoparticle-cell interactions in physiological media by atomic force microscopy, ACS Sustain Chem. Eng. 2 (2014) 1681-1690, https://doi.org/10.1021/sc500152g.

[20] X. Zhu, J. Wang, X. Zhang, Y. Chang, Y. Chen, The impact of ZnO nanoparticle aggregates on the embryonic development of zebrafish (Danio rerio), Nanotechnology 20 (2009) 195103, https://doi.org/10.1088/0957-4484/20/ 19/195103.

[21] L. Wang, C. Hu, L. Shao, The antimicrobial activity of nanoparticles: present situation and prospects for the future, Int. J. Nanomed. 12 (2017) 1227-1249, https://doi.org/10.2147/IJN.S121956.

[22] C. Kaweeteerawat, A. Ivask, R. Liu, H. Zhang, C.H. Chang, C. Low-Kam, H. Fischer, Z. Ji, S. Pokhrel, Y. Cohen, D. Telesca, J. Zink, L. Mädler, P.A. Holden, A. Nel, H. Godwin, Toxicity of metal oxide nanoparticles in Escherichia coli correlates with conduction band and hydration energies, Environ. Sci. Technol. 49 (2015) 1105-1112, https://doi.org/10.1021/es504259s.

[23] C. Lee, J.Y. Kim, W.I. Lee, K.L. Nelson, J. Yoon, D.L. Sedlak, Bactericidal effect of zero-valent iron nanoparticles on Escherichia coli, Environ. Sci. Technol. 42 (2008) 4927-4933, https://doi.org/10.1021/es800408u.

[24] Y. Li, W. Zhang, J. Niu, Y. Chen, Mechanism of photogenerated reactive oxygen species and correlation with the antibacterial properties of engineered metal-oxide nanoparticles, ACS Nano 6 (2012) 5164-5173, https://doi.org $10.1021 / \mathrm{nn} 300934 \mathrm{k}$.

[25] T. Xia, M. Kovochich, J. Brant, M. Hotze, J. Sempf, T. Oberley, C. Sioutas, J.I. Yeh, M.R. Wiesner, A.E. Nel, Comparison of the abilities of ambient and manufactured nanoparticles to induce cellular toxicity according to an oxidative stress paradigm, Nano Lett. 6 (2006) 1794-1807, https://doi.org/ $10.1021 / \mathrm{nl061025k}$.

[26] O. Bondarenko, A. Ivask, A. Käkinen, A. Kahru, Sub-toxic effects of CuO nanoparticles on bacteria: Kinetics, role of $\mathrm{Cu}$ ions and possible mechanisms of action, Environ. Pollut. 169 (2012) 81-89, https://doi.org/10.1016/j. envpol.2012.05.009.

[27] Z. Xiu, Q. Zhang, H.L. Puppala, V.L. Colvin, P.J.J. Alvarez, Negligible particlespecific antibacterial activity of silver nanoparticles, Nano Lett. 12 (2012) 4271-4275, https://doi.org/10.1021/nl301934w.

[28] I. Sondi, B. Salopek-Sondi, Silver nanoparticles as antimicrobial agent: a case study on E. coli as a model for Gram-negative bacteria, J. Colloid Interface Sci. 275 (2004) 177-182, https://doi.org/10.1016/j.jcis.2004.02.012.

[29] P. Sahoo, P.S. Murthy, S. Dhara, V.P. Venugopalan, A. Das, A.K. Tyagi, Probing the cellular damage in bacteria induced by GaN nanoparticles using confocal laser Raman spectroscopy, J. Nanoparticle Res. 15 (2013), https://doi.org/ 10.1007/s11051-013-1841-9.

[30] Y. Ibuki, T. Toyooka, Nanoparticle uptake measured by flow cytometry, in: Nanotoxicity, Humana Press, Totowa, NJ, 2012, pp. 157-166, https://doi.org/ 10.1007/978-1-62703-002-1_11.

[31] L.K. Adams, D.Y. Lyon, P.J.J. Alvarez, Comparative eco-toxicity of nanoscale TiO2, SiO2, and ZnO water suspensions, Water Res. 40 (2006) 3527-3532, https://doi.org/10.1016/j.watres.2006.08.004.

[32] T.J. Beveridge, Structures of gram-negative cell walls and their derived membrane vesicles, J. Bacteriol. 181 (1999) 4725-4733.

[33] J.J. Thwaites, N.H. Mendelson, Mechanical behaviour of bacterial cell walls, Adv. Microb. Physiol. 32 (1991) 173-222.

[34] M. Tokarska-Rodak, M. Kozioł-Montewka, K. Skrzypiec, T. Chmielewski, E. Mendyk, S. Tylewska-Wierzbanowska, Analysis of nanomechanical properties of Borrelia burgdorferi spirochetes under the influence of lytic factors in an in vitro model using atomic force microscopy, Postepy Hig. Med. Doswiadczalnej Online. 69 (2015) 1222-1227.

[35] B.-J. Park, N.I. Abu-Lail, Variations in the nanomechanical properties of virulent and avirulent listeria monocytogenes, Soft Matter. 6 (2010) 3898-3909, https://doi.org/10.1039/b927260g.

[36] V. Vadillo-Rodriguez, S.R. Schooling, J.R. Dutcher, In situ characterization of differences in the viscoelastic response of individual gram-negative and grampositive bacterial cells, J. Bacteriol. 191 (2009) 5518-5525, https://doi.org/ 10.1128/JB.00528-09.

[37] N.I. Abu-Lail, T.A. Camesano, The effect of solvent polarity on the molecular surface properties and adhesion of Escherichia coli, Colloids Surf. B Biointerfaces. 51 (2006) 62-70, https://doi.org/10.1016/j.colsurfb.2006.05. 009.

[38] G. Francius, P. Polyakov, J. Merlin, Y. Abe, J.-M. Ghigo, C. Merlin, C. Beloin, J.F.L. Duval, Bacterial surface appendages strongly impact nanomechanical and electrokinetic properties of escherichia coli cells subjected to osmotic stress, PLoS One 6 (2011), https://doi.org/10.1371/journal.pone.0020066.

[39] F. Gaboriaud, S. Bailet, E. Dague, F. Jorand, Surface structure and nanomechanical properties of shewanella putrefaciens bacteria at two $\mathrm{pH}$ values ( 4 and 10 ) determined by atomic force microscopy, J. Bacteriol. 187 (2005) 3864-3868, https://doi.org/10.1128/JB.187.11.3864-3868.2005.

[40] C.B. Volle, M.A. Ferguson, K.E. Aidala, E.M. Spain, M.E. Núñez, Quantitative changes in the elasticity and adhesive properties of Escherichia coli ZK1056 prey cells during predation by bdellovibrio bacteriovorus 109J, Langmuir ACS J. Surf. Colloids 24 (2008) 8102-8110, https://doi.org/10.1021/ la8009354.

[41] A. Raman, S. Trigueros, A. Cartagena, A.P.Z. Stevenson, M. Susilo, E. Nauman, S A. Contera, Mapping nanomechanical properties of live cells using multiharmonic atomic force microscopy, Nat. Nanotechnol. 6 (2011) 809-814, https://doi.org/10.1038/nnano.2011.186.

[42] N.P. Mortensen, J.D. Fowlkes, C.J. Sullivan, D.P. Allison, N.B. Larsen, S. Molin, M J. Doktycz, Effects of colistin on surface ultrastructure and nanomechanics of Pseudomonas aeruginosa cells, Langmuir ACS J. Surf. Colloids 25 (2009) 37283733, https://doi.org/10.1021/la803898g.

[43] A. da Silva, O. Teschke, Effects of the antimicrobial peptide PGLa on live Escherichia coli, Biochim. Biophys. Acta 1643 (2003) 95-103.

[44] A. Zdybicka-Barabas, S. Stączek, P. Mak, K. Skrzypiec, E. Mendyk, M. Cytryńska, Synergistic action of Galleria mellonella apolipophorin III and lysozyme against Gram-negative bacteria, Biochim. Biophys. Acta 2013 (1828) 14491456, https://doi.org/10.1016/j.bbamem.2013.02.004.

[45] G. Longo, S. Kasas, Effects of antibacterial agents and drugs monitored by atomic force microscopy: AFM study of the effects of antibacterial agents and drugs, Wiley Interdiscip. Rev. Nanomed. Nanobiotechnol. 6 (2014) 230-244, https://doi.org/10.1002/wnan.1258.

[46] S. Aguayo, N. Donos, D. Spratt, L. Bozec, Single-bacterium nanomechanics in biomedicine: unravelling the dynamics of bacterial cells, Nanotechnology 26 (2015) 062001, https://doi.org/10.1088/0957-4484/26/6/062001.

[47] A.V. Bolshakova, O.I. Kiselyova, I.V. Yaminsky, Microbial surfaces investigated using atomic force microscopy, Biotechnol. Prog. 20 (2004) 1615-1622. https://doi.org/10.1021/bp049742c.

[48] F. Gaboriaud, Y.F. Dufrêne, Atomic force microscopy of microbial cells: Application to nanomechanical properties, surface forces and molecular 
recognition forces, Colloids Surf. B Biointerfaces 54 (2007) 10-19, https://doi. org/10.1016/j.colsurfb.2006.09.014.

[49] D.J. Muller, AFM: a nanotool in membrane biology, Biochemistry (Mosc.) 47 (2008) 7986-7998, https://doi.org/10.1021/bi800753x.

[50] H.-J. Butt, B. Cappella, M. Kappl, Force measurements with the atomic force microscope: Technique, interpretation and applications, Surf. Sci. Rep. 59 (2005) 1-152, https://doi.org/10.1016/j.surfrep.2005.08.003.

[51] T.G. Kuznetsova, M.N. Starodubtseva, N.I. Yegorenkov, S.A. Chizhik, R.I. Zhdanov, Atomic force microscopy probing of cell elasticity, Micron. 38 (2007) 824-833, https://doi.org/10.1016/j.micron.2007.06.011.

[52] A. Simon, T. Cohen-Bouhacina, M.C. Porté, J.P. Aimé, J. Amédée, R. Bareille, C. Baquey, Characterization of dynamic cellular adhesion of osteoblasts using atomic force microscopy: osteoblast adhesion by atomic force microscopy, Cytometry A 54A (2003) 36-47, https://doi.org/10.1002/cyto. a.10052.

[53] K. Amako, K. Murata, A. Umeda, Structure of the envelope of escherichia coli observed by the rapid-freezing and substitution fixation method, Microbiol. Immunol. 27 (1983) 95-99, https://doi.org/10.1111/j.1348-0421.1983. tb03571.x.

[54] R. Brayner, R. Ferrari-Iliou, N. Brivois, S. Djediat, M.F. Benedetti, F. Fiévet, Toxicological impact studies based on Escherichia coli bacteria in ultrafine $\mathrm{ZnO}$ nanoparticles colloidal medium, Nano Lett. 6 (2006) 866-870, https://doi.org/ $10.1021 /$ nl052326h.

[55] W. Tan, K. Wang, X. He, X.J. Zhao, T. Drake, L. Wang, R.P. Bagwe, Bionanotechnology based on silica nanoparticles, Med. Res. Rev. 24 (2004) 621-638, https://doi.org/10.1002/med.20003.

[56] J. Wehling, E. Volkmann, T. Grieb, A. Rosenauer, M. Maas, L. Treccani, K. Rezwan, A critical study: Assessment of the effect of silica particles from 15 to $500 \mathrm{~nm}$ on bacterial viability, Environ. Pollut. 176 (2013) 292-299, https://doi. org/10.1016/j.envpol.2013.02.001.

[57] L.B. Capeletti, L.F. de Oliveira, K. de A. Gonçalves, J.F.A. de Oliveira, Â. Saito, J. Kobarg, J.H.Z. dos Santos, M.B. Cardoso, Tailored silica-antibiotic nanoparticles: overcoming bacterial resistance with low cytotoxicity, Langmuir 30 (2014) 7456-7464, https://doi.org/10.1021/la4046435.

[58] C. Fruijtier-Pölloth, The toxicological mode of action and the safety of synthetic amorphous silica-A nanostructured material, Toxicology 294 (2012) 61-79, https://doi.org/10.1016/j.tox.2012.02.001.

[59] I. Gammoudi, M. Mathelie-guinlet, F. Morote, L. Beven, D. Moynet, C. Graubyheywang, T. Cohen-bouhacina, Morphological and nanostructural surface changes in Escherichia coli over time, monitored by atomic force microscopy, Colloids Surf. B Biointerfaces 141 (2016) 355-364, https://doi. org/10.1016/j.colsurfb.2016.02.006.

[60] A.L. Weisenhorn, P.K. Hansma, T.R. Albrecht, C.F. Quate, Forces in atomic force microscopy in air and water, Appl. Phys. Lett. 54 (1989) 2651-2653, https:// doi.org/10.1063/1.101024.

[61] A.J. Engler, F. Rehfeldt, S. Sen, D.E. Discher, Microtissue elasticity: measurements by atomic force microscopy and its influence on cell differentiation, in: Methods Cell Biol., Academic Press, 2007, pp. 521-545, https://doi.org/10.1016/S0091-679X(07)83022-6.

[62] G. Thomas, N.A. Burnham, T.A. Camesano, Q. Wen, Measuring the mechanical properties of living cells using atomic force microscopy, J. Vis. Exp. (2013), https://doi.org/10.3791/50497.

[63] A.V. Bolshakova, O.I. Kiselyova, A.S. Filonov, O.Y. Frolova, Y.L. Lyubchenko, I. V. Yaminsky, Comparative studies of bacteria with an atomic force microscopy operating in different modes, Ultramicroscopy 86 (2001) $121-128$.

[64] A. Cerf, J.-C. Cau, C. Vieu, E. Dague, Nanomechanical properties of dead or alive single-patterned bacteria, Langmuir 25 (2009) 5731-5736, https://doi.org/ 10.1021/la9004642.

[65] F. Gaboriaud, B.S. Parcha, M.L. Gee, J.A. Holden, R.A. Strugnell, Spatially resolved force spectroscopy of bacterial surfaces using force-volume imaging, Colloids Surf. B Biointerfaces 62 (2008) 206-213, https://doi.org/10.1016/ j.colsurfb.2007.10.004.

[66] G. Longo, L.M. Rio, C. Roduit, A. Trampuz, A. Bizzini, G. Dietler, S. Kasas, Force volume and stiffness tomography investigation on the dynamics of stiff material under bacterial membranes: force volume and stiffness tomography analysis of bacterial membranes, J. Mol. Recognit. 25 (2012) 278-284, https:// doi.org/10.1002/jmr.2171.
[67] M. Hu, J. Wang, H.Zhao, S. Dong, J. Cai, Nanostructure and nanomechanics analysis of lymphocyte using AFM: from resting, activated to apoptosis, J. Biomech. 42 (2009) 1513-1519, https://doi.org/10.1016/j.jbiomech.2009.03.051.

[68] R.J. Emerson, T.A. Camesano, Nanoscale investigation of pathogenic microbial adhesion to a biomaterial, Appl. Environ. Microbiol. 70 (2004) 6012-6022. https://doi.org/10.1128/AEM.70.10.6012-6022.2004.

[69] L. Arnal, D.O. Serra, N. Cattelan, M.F. Castez, L. Vázquez, R.C. Salvarezza, O.M Yantorno, M.E. Vela, Adhesin contribution to nanomechanical properties of the virulent bordetella pertussis envelope, Langmuir. 28 (2012) 7461-7469, https://doi.org/10.1021/la300811m.

[70] A. Méndez-Vilas, A.M. Gallardo-Moreno, M.L. González-Martín, Atomic force microscopy of mechanically trapped bacterial cells, Microsc. Microanal. 13 (2007) 55-64, https://doi.org/10.1017/S1431927607070043.

[71] M. Arnoldi, M. Fritz, E. Bäuerlein, M. Radmacher, E. Sackmann, A. Boulbitch, Bacterial turgor pressure can be measured by atomic force microscopy, Phys. Rev. E. 62 (2000) 1034.

[72] C.J. Sullivan, S. Venkataraman, S.T. Retterer, D.P. Allison, M.J. Doktycz, Comparison of the indentation and elasticity of E. coli and its spheroplasts by AFM, Ultramicroscopy 107 (2007) 934-942, https://doi.org/10.1016/j. ultramic.2007.04.017.

[73] C.B. Volle, M.A. Ferguson, K.E. Aidala, E.M. Spain, M.E. Núñez, Spring constants and adhesive properties of native bacterial biofilm cells measured by atomic force microscopy, Colloids Surf. B Biointerfaces 67 (2008) 32-40, https://doi. org/10.1016/j.colsurfb.2008.07.021.

[74] S.B. Velegol, B.E. Logan, Contributions of bacterial surface polymers, electrostatics, and cell elasticity to the shape of AFM force curves, Langmuir 18 (2002) 5256-5262, https://doi.org/10.1021/la011818g.

[75] P. Eaton, J.C. Fernandes, E. Pereira, M.E. Pintado, F. Xavier Malcata, Atomic force microscopy study of the antibacterial effects of chitosans on Escherichia col and Staphylococcus aureus, Ultramicroscopy 108 (2008) 1128-1134, https:/ doi.org/10.1016/j.ultramic.2008.04.015.

[76] G. Francius, O. Domenech, M.P. Mingeot-Leclercq, Y.F. Dufrêne, Direct observation of staphylococcus aureus cell wall digestion by lysostaphin, J. Bacteriol. 190 (2008) 7904-7909, https://doi.org/10.1128/JB.01116-08.

[77] C. Formosa, M. Grare, E. Jauvert, A. Coutable, J.B. Regnouf-de-Vains, M. Mourer R.E. Duval, E. Dague, Nanoscale analysis of the effects of antibiotics and CX1 on a Pseudomonas aeruginosa multidrug-resistant strain, Sci. Rep. 2 (2012) https://doi.org/10.1038/srep00575.

[78] A. da S. Junior, O. Teschke, Dynamics of the antimicrobial peptide PGLa action on $<$ Emphasis Type="Italic" $>$ Escherichia coli $<$ Emphasis $>$ monitored by atomic force microscopy, World J. Microbiol. Biotechnol. 21 (2005) 1103-1110, https://doi.org/10.1007/s11274-005-0077-y.

[79] M. Meincken, D.L. Holroyd, M. Rautenbach, Atomic force microscopy study of the effect of antimicrobial peptides on the cell envelope of Escherichia coli, Antimicrob. Agents Chemother. 49 (2005) 4085-4092, https://doi.org/ 10.1128/AAC.49.10.4085-4092.2005.

[80] F. Quilès, S. Saadi, G. Francius, J. Bacharouche, F. Humbert, In situ and real time investigation of the evolution of a Pseudomonas fluorescens nascent biofilm in the presence of an antimicrobial peptide, Biochim. Biophys. Acta BBA Biomembr. 2016 (1858) 75-84, https://doi.org/10.1016/j.bbamem.2015.10.015.

[81] B. Ramalingam, T. Parandhaman, S.K. Das, Antibacterial effects of biosynthesized silver nanoparticles on surface ultrastructure and nanomechanical properties of gram-negative bacteria viz. Escherichia coli and Pseudomonas aeruginosa, ACS Appl. Mater. Interfaces 8 (2016) 4963-4976, https://doi.org/10.1021/acsami.6b00161.

[82] S. Jan, F. Baron, M. Alabdeh, W. Chaari, N. Grosset, M.-F. Cochet, M. Gautier, V. VíE, F. Nau, Biochemical and micrographic evidence of escherichia coli membrane damage during incubation in egg white under bactericidal conditions, J. Food Prot. 76 (2013) 1523-1529, https://doi.org/10.4315/0362028X.JFP-12-418.

[83] T. Hugel, M. Grosholz, H. Clausen-Schaumann, A. Pfau, H. Gaub, M. Seitz Elasticity of single polyelectrolyte chains and their desorption from solid supports studied by AFM based single molecule force spectroscopy, Macromolecules 34 (2001) 1039-1047, https://doi.org/10.1021/ma0009404.

[84] Y. Wei, R.A. Latour, Correlation between desorption force measured by atomic force microscopy and adsorption free energy measured by surface plasmon resonance spectroscopy for peptide - surface interactions, Langmuir 26 (2010) 18852-18861, https://doi.org/10.1021/la103685d. 